Domingo Molfi

\title{
PANORAMA UNIVERSAL
}

\section{MAHATMA GANDHI Y LA INDIA}

(JADA cierto tiempo, Mahatma Gandhi, el apóstol de la resistencia pasiva, renueva el arduo problema del antagonismo entre la India de la quietud y del Nirvana y el Occidente tumultuoso y febril. Inglaterra, entre tanto, no renuncia a sus privilegios seculares. El Gandhi levanta las masas, las conmueve con el hálito de sus palabras ardientes y opone a la civilización inglesa y a sus métodos de penetración, la no cooperación, el valor tranquilo de morir sin matar. Maltratado, odiado por los opresores, apaleado, preso, Gandhi no se desalienta.

El pensamiento de Gandhi está contra el progreso. Niega el progreso, porque considera que la civilización europea ha perdido ya el contacto con el alma sencilla, dulce y evangélica y sólo adora al dinero. La gran guerra, según Gandhi, reveló el carácter satánico de una civilización; todas las leyes de la moral fueron violadas y humilladas y en ella resurgió el espíritu agresivo e implacable de los adoradores de Mammon. Para Gandhi, la civilización ha 
perturbado la milenaria alma india. El maquinismo es un gran pecado, serviliza a los pueblos.

Evitemos-ha dicho Gandhi--el ser íntimos con aquellos cuyos usos y costumbres sociales son distintos a los nuestros. No hay que entrelazar la vida con la de los hombres o los pueblos cuyo ideal está en desacuerdo con el nuestro. Cada hombre es un arroyo. Cada pueblo es un río. Deben seguir su lecho limpio y sin mancha, hasta que hayan alcanzado el mar de la salvación, donde todos se mezclarán.

Parece ser esto un eco de las sagradas escrituras hindúes, que contienen en esencia esta doctrina:

Tu propio Dharma aunque vacío de méritos es el mejor. La realización de un Dharma que no es el tuyo siempre está rodeada de peligros. Desde millares de años-agregala India inquebrantablemente permanece sola, en medio de la ola cambiante de los imperios. Todo lo demás ha pasado. Ella ha sabido conquistar, desde millares de años, el dominio de sí y de la ciencia de la felicidad. En esto nada tiene que aprender de los otros. No ha querido el maquinismo y las grandes ciudades. La antigua carreta, la rueca, la vieja educación indígena, han asegurado su sabiduría y su bien. Nos es preciso volver a la simplicidad antigua, no de un golpe sin duda, pero poco a poco, pacientemente, dando cada uno el ejemplo.

En Kim de Rudyard Kipling, el hermoso poema. de la penetración inglesa, de las más bellas de entre sus novelas, se intenta la contraposición entre el viejo místico de la India y el impetuoso adolescente irlandés. Oriente frente a Occidente. Y aun cuando en el libro siguen ambos en demanda de la Ruta de las Cosas y atraviesan los senderos innumerables del misticismo, y duermen bajo la misma tienda y comen en el mismo plato, cada uno saborea una vida interior distinta y sus almas permanecen herméticas $e$ indescifrables. Kim es inglés; por lo tanto no le interesa ni la Ley Suprema del místico Teshoo ni 
el río milagroso cuya corriente buscan en el misterio de la tierra infinita de la India. Kim es activo, audaz, impulsivo, rapaz. El asiático quiere el anihilamiento de la personalidad, busca el Nirvana, la beatitud eterna; el inglés es individualista, es práctico, simulador. En realidad no camina hacia el río de Budha sino tras las huellas de ciertos agentes secretos del gobierno ruso para robarles sus papeles que son necesarios al gobierno británico. De paso observa las costumbres, aprende la lengua, interviene en los menudos actos de la vida secreta de los habitantes. Sigue el sistema de la penetración. Se finge discípulo para mejor sorprender los misterios. En Kim alienta, en pequeño, la imagen del imperialismo.

Contra este duelo se levanta Gandhi, el apóstol. Gandhi conoció de cerca la civilización europea. Viajó por el continente y luego fué a Bombay a ejercer su profesión de abogado. Pero renunció pronto a ella para dedicarse enteramente a predicar su doctrina, la salvación de la India. Recuérdense sus primeras actuaciones en el Africa del Sur, cuando fué llamado allí por más de 150 mil compatriotas que sufrían humillaciones y contribuciones agotadoras. Carecían de fuerza para defenderse. Gandhi inició entonces la lucha formidable de una conciencia contra una fuerza material organizada. Su doctrina de la no cooperación prendió pronto en las almas. Fundó una colonia agrícola, siguiendo las enseñanzas de Tolstoy, y repartió tierras a los colonos. El éxodo de las masas de hindúes paralizó la vida industrial del Africa del Sur y Gandhi venció en la prueba. No obstante estos éxitos, Gandhi concedía treguas al dominio inglés y se convertía en un ciudadano del Imperio. Su doctrina era no sólo de no resistencia sino de perdón y de amor. Fué así cómo durante la guerra boer formó una Cruz Roja india y durante la terrible peste de Johannesburg organizó un hospital. 
Sin embargo, estas muestras de amor y de perdón no lograron deterner la furia xenófoba. En diversas ocasiones fué hecho prisionero, condenado a reclusión, puesto en una jaula, atado de pies y manos, humillado, golpeado por el populacho furioso, por muchos a quienes él había servido, y dejado como muerto. A pesar de todas esas crueldades, Gandhi se mantuvo en el centro de su fe. No se alteró, no se violentó. Esperaba, simplemente. Ha continuado siempre esperando, a pesar de todos los sufrimientos posteriores. Hoy mismo, que ha vuelto a caer prisionero, espera, porque las ideas en el alma india pueden esperar siglos sin que jamás envejezcan ni pierdan su fuerza. Sólo tiene valor el sacrificio en el alma indomable del predicador. $Y$ mientras mayores sean los sufrimientos, más limpio y diáfano brillará el espíritu. En la India, donde su poder es inmenso, Gandhi nunca ha dejado de desarrollar su doctrina vital, de resistencia pasiva al dominio inglés, cuya civilización hiere lo más íntimo de su ser. La no cooperación, según Gandhi, no está dirigida contra el Occidente, sino contra la civilización material y contra la explotación de los débiles que resulta de ella. Es más bien la defensa de las tradiciones, por medio de un nacionalismo exclusivo, estrecho, sin contacto con el mundo exterior.

Así ha surgido el desarrollo de la doctrina de Gandhi. Inmensas explosiones de sentimiento religioso han conmovido a la India. Durante casi un cuarto de siglo de lucha, sin vacilaciones, acorazado por la fe, Gandhi ha combatido, incansable, sufriendo penurias pero sin abandonar jamás las ideas fundamentales. Su intervención misteriosa ha tocado todos los corazones orientales. Bajo su prestigio se han unido los poderes morales que parecían más antagónicos. Los musulmanes, enemigos tradicionales del brahmanismo, han librado junto a él batallas ardorosas. $Y$ así 
ha podido unir en un misticismo esencial, en una lección constante de amor, los credos más opuestos. Centenares de hombres han ido al sacrificio $y$ a la muerte con un heroísmo silencioso y ejemplar. Ninguna fuerza material, ninguna presión violenta ha podido doblegarlos. Por el contrario, el sacrificio es para ellos la purificación, el Dharma potente que ilumina todas las voluntades.

Por su parte Inglaterra no renuncia a sus privilegios en homenaje a su evangelio de amor, porque tiene la conciencia de su misión civilizadora y de los grandes beneficios implantados en la India. El credo de Gandhi es sin duda noble y generoso, pero es anacrónico.

$\mathrm{El}$ imperialismo tiene entre sus manos el sistema bancario, las finanzas, las industrias, el comercio, los transportes, los servicios públicos. La dominación económica articula y fortalece la dominación política. La independencia nacional se convierte así en una aspiración teórica sin base. Al lado de las grandes masas que conmueve y levanta Gandhi, se inmovilizan otras masas inmensas que no cooperan al impulso doctrinario del apóstol. Al lado de los nacionalistas ardientes, la pasividad de los egoístas. Este cuadro de los países coloniales, dominados por el impexialismo, es, en resumen, el cuadro de los países que sufren la servidumbre económica respecto de los países de gran potencia financiera. La América del Sur casi en su totalidad está supeditada al capital imperialista. Una red apretada de hilos la une y la somete. Sus gobiernos tienen una ilusión de libertad. En el fondo viven para servir deudas. Cada país tiene el sello de las colonias. $\mathrm{Y}$ toda su actividad industrial y comercial vive de prestado, equilibrando en movimientos inverosímiles su empobrecida vida independiente. 